ORIGINAL ARTICLE / ARTIGO ORIGINAL

\title{
Application of the Respondent-Driven Sampling methodology in a biological and behavioral surveillance survey among female sex workers, Brazil, 2016
}

\section{Aplicação da metodologia Respondent-Driven Sampling em pesquisa biológica e comportamental com mulheres trabalhadoras do sexo, Brasil, 2016}

\author{
Giseli Nogueira Damacena' (D), Célia Landmann Szwarcwald', Paulo Roberto Borges de \\ Souza Júnior', Orlando da Costa Ferreira Júnior", Wanessa da Silva de Almeida', \\ Ana Roberta Pati Pascom"', Maria Cristina Pimenta"', The Brazilian FSW Group*
}

\begin{abstract}
Introduction: Respondent-Driven Sampling (RDS) has been used in surveys with key populations at risk of HIV infection, such as female sex workers (FSW). This article describes the application of the RDS method among FSW in 12 Brazilian cities, during a survey carried out in 2016. Methodology: A biological and behavioral surveillance study carried out in 12 Brazilian cities, with a minimum sample of $350 \mathrm{FSW}$ in each city. Tests were performed for HIV, syphilis, and hepatitis B and C infections. A social-behavioral questionnaire was also applied. Results: The sample was comprised of 4,328 FSW. For data analysis, the sample was weighted according to each participant's network size (due consideration to the implications of RDS complex design and to the effects of homophilia are recommended). Discussion: Although RDS methods for obtaining a statistical sample are based on strong statistical assumptions, allowing for an estimation of statistical parameters, with each new application the method has been rethought. In the analysis of whole-sample data, estimators were robust and compatible with those found in 2009. However, there were significant variations according to each city. Conclusion: The achieved sample size was of great relevance for assessing progress and identifying problems regarding the prevention and treatment of Sexually Transmitted Infections. New RDS studies with more time and operational resources should be envisaged. This could further network development.
\end{abstract}

Keywords: Respondent-Driven Sampling. Sex workers. HIV. Syphilis. Hepatitis. Brazil.

*Célia Landmann Szwarcwald, Paulo Roberto Borges de Souza Júnior, Orlando C. Ferreira Jr., Giseli Nogueira Damacena, Neide Gravato da Silva, Rita Bacuri, Helena Brigido, Hermelinda Maia Macena, Ana Brito, Inês Dourado, Mark Drew Crosland Guimarães, Wanessa da Silva de Almeida, Alexandre Grangeiro, Carla Luppi, Karin Regina Luhm, Isete Maria Stella, Adriana Varela Espinola, Tânia Varela, and Francisca Sueli da Silva.

Institute of Scientific and Technological Communication and Information in Health, Oswaldo Cruz Foundation - Rio de Janeiro (RJ), Brazil.

"Institute of Biology, Universidade Federal do Rio de Janeiro - Rio de Janeiro (RJ), Brazil.

I'Department of Chronic Condition Diseases and Sexually Transmitted Infections, Ministry of Health - Brasília (DF), Brazil.

Corresponding author: Giseli Nogueira Damacena. Avenida Brasil, 4365, Pavilhão Haity Moussatché, 20 floor, room 225, CEP: 21040-900, Manguinhos, Rio de Janeiro, RJ, Brazil. E-mail: damacenagn@gmail.com

Conflict of interests: nothing to declare - Financial support: United Nations Educational, Scientific and Cultural Organization (UNESCO). 
RESUMO: Introdução: O método de amostragem Respondent-Driven Sampling (RDS) tem sido utilizado em inquéritos com populações-chave sob maior risco de infecção pelo HIV, como as mulheres trabalhadoras do sexo (MTS). Este artigo tem o objetivo de descrever a implementação do RDS entre MTS em 12 cidades brasileiras em 2016. Metodologia: Trata-se de um estudo de vigilância biológica e comportamental realizado em 12 cidades brasileiras, com amostra mínima de 350 MTS em cada cidade. Foram realizados testes para infecções por HIV, sífilis, hepatites B e C, e aplicou-se questionário sociocomportamental. Resultados: Participaram 4.328 MTS. Para a análise dos dados, foi elaborada uma ponderação amostral considerando o tamanho da rede de cada participante; recomenda-se que o desenho complexo de amostragem por RDS e o efeito de homofilia sejam considerados. Discussão: Apesar de o RDS ser fundamentado em pressupostos estatísticos para obtenção de uma amostra probabilística e possibilitar estimação de parâmetros estatísticos, ele vem sendo repensado a cada nova aplicação. $\mathrm{Na}$ análise dos dados na totalidade da amostra, os estimadores mostraram-se robustos e coerentes aos encontrados em 2009. Entretanto, constataram-se grandes variações por cidade. Conclusão: O tamanho amostral alcançado foi de grande relevância para avaliar avanços e identificar problemas a respeito da prevenção e assistência às infecções sexualmente transmissíveis. Ressalta-se a necessidade de pensar estudos RDS com maior tempo e recursos para implementação, o que poderia permitir um melhor desenvolvimento das redes.

Palavras-chave: Respondent-Driven Sampling. Profissionais do sexo. HIV. Sífilis. Hepatite. Brasil.

\section{INTRODUCTION}

In the early 1980s, the HIV/AIDS epidemic emerged in Brazil, characterized by low prevalence in the general population (less than 1\%), and high prevalence in key populations, high-risk subgroups: drug users (DU), men who have sex with men (MSM), and female sex workers $(\mathrm{FSW})^{1,2}$.

Demographically small and associated with stigmatized behavior or illegal activities, these groups are difficult to access, rendering traditional sampling techniques inadequate $e^{3-5}$. Probabilistic sampling methods were developed in the mid-1990s to enable the estimation of parameters of interest in these key populations. One example is Respondent-Driven Sampling (RDS), a variant of chain sampling in which study participants themselves invite peers from their own population to participate. RDS has been used in several countries ${ }^{5-9}$.

In Brazil, there are important efforts in the development of studies to characterize the practices and risk behavior of these key populations ${ }^{2}$. In 2009, RDS surveys were conducted among MSM, FSW and DU in 10 Brazilian cities. The method had been elected by the Ministry of Health as adequate for key-population research in the country ${ }^{5,10,11}$. In 2016, continuing the government's commitment to HIV / AIDS surveillance, new biological and behavioral surveys were carried out in 12 Brazilian cities, this time involving MSM, FSW, and transgender and transvestite women (TTW). The surveys employed RDS as a statistical subsidy for the formulation of public policies targeting these groups ${ }^{12-14}$.

Regarding FSW, international studies indicate high levels of HIV prevalence in this group: in India, $16 \%$; in Nigeria, 50 to $70 \%$ (and only 2.3 to $3.8 \%$ in the general population) ${ }^{15-18}$. 
In Brazil, the FSW group is estimated to represent $0.8 \%$ of the female population aged 15 to 49 - over half a million women. HIV prevalence in this group is much higher than in the general Brazilian female population ${ }^{19-20}$.

This article describes the implementation of the RDS sampling method in a 2016 FWS survey carried out in 12 Brazilian cities.

\section{METHOD}

The "Comprehensive Nationwide Study on Female Sex Workers' Behavior, Attitudes, Practices, and Prevalence of HIV, Syphilis and Hepatitis B and C - Health Chain Project II" (Estudo de abrangência nacional de comportamentos, atitudes, práticas e prevalência de HIV, sifilis e hepatites $B e$ $C$ entre mulheres profissionais do sexo - Projeto Corrente da Saúde II) was conducted in 2016. It was comprised of a biological and behavioral surveillance research, with testing for HIV infection, syphilis, and hepatitis B and C, together with the application of a socio-behavioral questionnaire.

The research project was approved by Oswaldo Cruz Foundation's Research Ethics Committee (Protocol number 1,338,989), and followed the guidelines of the National Health Council, ensuring voluntary participation and anonymity to all interviewees. All respondents signed an Term of Free and Informed Consent (TFIC), and were allowed to discontinue their participation at any time.

\section{STUDY DESIGN AND ELIGIBILITY}

The study was conducted in 12 Brazilian cities: Manaus, Belém, Fortaleza, Recife, Salvador, Belo Horizonte, Rio de Janeiro, São Paulo, Curitiba, Porto Alegre, Brasília, and Campo Grande. Data was collected between June and November 2016.

A predefined minimum sample size of 350 valid interviews per city resulted in a predefined minimum total sample of 4,200 FSW. In some municipalities the sample exceeded the predefined minimum, so the study's actual total sample amounted to 4,328 interviewed FSW (Table 1). The included cities and minimum sample size were established by the Ministry of Health's Department of Chronic Condition Diseases and Sexually Transmitted Infections (Departamento de Doenças de Condições Crônicas e Infecções Sexualmente Transmissíveis - DCCI), according to geographic and epidemiological-relevance criteria affecting HIV/AIDS prevalence in Brazil.

Eligibility criteria were: (1) to be biologically female; (2) to be at least 18 years old; (3) to be a sex worker in one of the surveyed municipalities; (4) to have exchanged sex for money at least once in the four months prior to the study; (5) to be in possession of a valid coupon; (6) no participation in the previous iteration of the survey; (7) to show no signs of being under the influence of drugs or alcohol at the time of participation; (8) to voluntarily accept the invitation, signing an TFIC. 


\section{FIELD WORK, ORGANIZATION AND TEAM TRAINING}

Prior to data collection, a preparatory survey was conducted between January and March 2016, in order to facilitate the study's implementation in each city. Focus groups and/or in-depth interviews were conducted with the FSW and their local representations ${ }^{21}$. In this process, the following preparatory data was sought: main prostitution zones in the city; diversity of FSW types; FSW interest in educational and promotional materials; optimal survey locale and service schedule; possible "seeds" (as explained below); focal points, leaders and NGOs to encourage study participation and assist recruitment.

In each city, 5 to 10 initial participants - the so-called "seeds" (Table 1) — were non-randomly chosen. These had varied individual characteristics, in an attempt to encompass the diversity of existing FSW types ${ }^{22}$.

In the RDS method, recruitment is performed by distributing a fixed number of coupons to each participant ${ }^{7}$. These coupons contain a serial number that is later used for social network design and recruitment pattern analysis ${ }^{23}$. Each participant was given three coupons, in accordance with the model used in the 2009 survey $^{5}$. The average number of invitees who effectively participated in the survey ranged from 2.3 to 2.8 (Table 1).

Table 1. Sample size, number of seeds, and average number of invitees per city, 2016.

\begin{tabular}{|c|c|c|c|c|c|}
\hline \multirow{2}{*}{ City } & \multicolumn{2}{|c|}{ Participants } & \multicolumn{2}{|c|}{ Seeds } & \multirow{2}{*}{$\begin{array}{c}\text { Average number } \\
\text { of invitees } \\
n\end{array}$} \\
\hline & $n$ & $\%$ & $\mathrm{~N}$ & $\%$ & \\
\hline Manaus & 358 & 8.3 & 5 & 6 & 2.7 \\
\hline Belém & 351 & 8.1 & 7 & 8.4 & 2.7 \\
\hline Fortaleza & 352 & 8.1 & 6 & 7.2 & 2.8 \\
\hline Recife & 354 & 8.2 & 5 & 6 & 2.7 \\
\hline Salvador & 350 & 8.1 & 10 & 12 & 2.6 \\
\hline Belo Horizonte & 350 & 8.1 & 7 & 8.4 & 2.3 \\
\hline Rio de Janeiro & 429 & 9.9 & 7 & 8.4 & 2.6 \\
\hline São Paulo & 368 & 8.5 & 9 & 10.8 & 2.4 \\
\hline Curitiba & 350 & 8.1 & 9 & 10.8 & 2.5 \\
\hline Porto Alegre & 353 & 8.2 & 6 & 7.2 & 2.8 \\
\hline Campo Grande & 352 & 8.1 & 5 & 6 & 2.7 \\
\hline Brasília & 361 & 8.3 & 7 & 8.4 & 2.5 \\
\hline Total & 4,328 & 100 & 83 & 100 & 2.6 \\
\hline
\end{tabular}


Each coupon was tagged with an RDS Code, in order to prevent fraud and enable the subsequent identification of recruitment patterns. The RDS Code consisted of two letters (city name initials), followed by a number and a letter (seed identification) and a set of numbers (wave identification) (Figure 1).

\section{RJ.1.A.1000.0000.} 0000.00

RJ.1.A.1100.0000. 0000.00

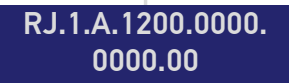

RJ.1.A.1310.0000. 0000.00

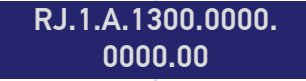

RJ.1.A.1320.0000. 0000.00

\section{RJ.1.A.1330.0000.} 0000.00

Figure 1. Model for network recruitment identification code used in coupons, 2016.

Fieldwork was carried out in health facilities, except in Rio de Janeiro and Belo Horizonte, where the participating FSW indicated other places, which were easier for them to access.

The survey staff was divided into a central team and individual city teams. The central team was composed of a general coordinator, a deputy coordinator, a field coordinator, a laboratory coordinator, and an information collection and monitoring coordinator. The city teams were composed of a coordinator, a supervisor, a counselor, an interviewer, a phlebotomist, and a test applicator (Figure 2).

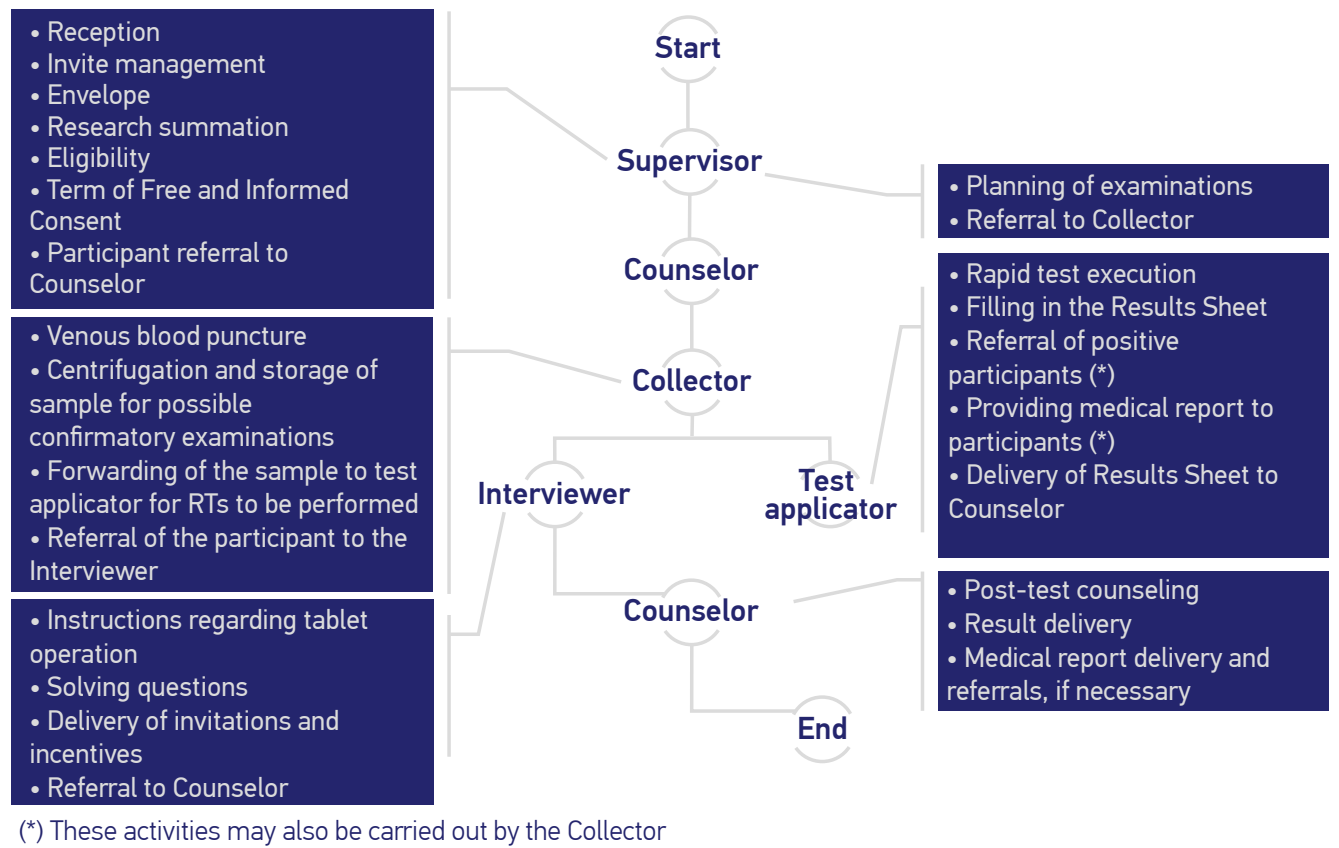

Figure 2. FSW participation flow, 2016. 
The city teams were trained by the central coordination in the health units where the research was conducted. This provided knowledge on local dynamics and organization. Test applicators underwent centralized training at the Molecular Virology Laboratory of the Federal University of Rio de Janeiro (LVM/UFRJ), led by the study's laboratory coordinator.

\section{DATA COLLECTION INSTRUMENTS}

Microsoft Access software was used to develop a program called Invitation Manager, operated by the supervisor. The program had the following purposes: to generate and print labels with the RDS Code; to fill in individual FSW's eligibility information and social network size; to store rapid test (RT) results; to track fieldwork by means of a task backlog and a picture of the local network - which acquired a more defined form as the number of participants grew - interfaced with $R$ software's RDS library ${ }^{24}$.

The socio-behavioral questionnaire was elaborated in collaboration with the DCCI and included the following modules: FSW sociodemographic and work characteristics; knowledge about HIV transmission and other sexually transmitted infections (STIs); social support and access to educational and preventive materials; frequency of HIV, syphilis, and hepatitis B and C tests; health status and health care insurance status; violence; sexual behavior with steady partners and clients; alcohol and drug use. The socio-behavioral questionnaire was developed in the SurveyMonkey system ${ }^{25}$, and answered via internet, allowing realtime monitoring by the central coordination. A trained interviewer applied the questionnaire, with the aid of a tablet, in a private place, thus maintaining participants' anonymity.

\section{RECRUITMENT INCENTIVES}

All interviewees received primary incentives such as snacks, personal care items, condoms and lubricants, as well as BRL 10 for transportation expenses. There were also secondary incentives, given to the participants for up to three successful recruitment referrals. Each successful referral paid BRL 30, totaling a maximum of BRL 90.

\section{LABORATORY TESTS (HIV, SYPHILIS, HEPATITIS B AND C)}

Rapid tests (RTs) for HIV, syphilis, HBV and HCV were performed, in accordance with DCCI recommendations ${ }^{26}$. Two $5 \mathrm{~mL}$ EDTA tubes-worth of venous blood were collected, and participants' RDS Code labels were attached to them. One tube was separated for the RTs; the other, containing a gel plug, was centrifuged to separate the plasma, and stored in a freezer at $20{ }^{\circ} \mathrm{C}$ until transfer to the LVM/UFRJ, where confirmatory tests were performed. Confirmatory testing was performed only when RTs had at least one reactive result for the assayed infections. In case of no reactive test, the frozen tube was discarded. Participants who refused venous blood collection were offered the option of performing the RT via fingerstick capillary sampling, without confirmatory examinations. 
RT results were delivered to the interviewees during post-test counseling. In case of a reactive result, the participant was informed that the RTs were for triage and that she would be referred to the public health service for confirmatory tests and follow-up.

Antibodies were assayed using the following RTs: HIV (HIV Test Bioeasy, Standard Diagnostic Inc., Korea, and ABON HIV 1/2/O Tri-Line Human Immunodeficiency Virus Rapid Test Device, China); Treponemal syphilis test (SD BIOLINE Syphilis 3.0, Standard Diagnostic Inc., Korea), HBV (Vikia HBsAg, BioMérieux SA, France) and HCV (ALERE HCV, Standard Diagnostic Inc., Korea). According to the DCCI recommendation, a reactive result on the initial HIV RT (HIV Test Bioeasy, Standard Diagnostic Inc., Korea) should be followed by a second HIV RT from a different manufacturer (ABON HIV 1/2/O Tri-Line Human Immunodeficiency Virus Rapid Test Device, China).

Confirmatory tests used in the study were: HIV-1 Western Blot for HIV (Cambridge Biotech HIV-1 Western Blot Kit, Maxim Biomedical, Inc., USA); rapid plasma reagin (RPR) for syphilis (RPR Syphilis, WAMA Diagnóstica, Brazil); viral load for HBV (Abbott RealTime HBV viral load assay, Abbott Laboratories, USA) and HCV (Abbott RealTime HCV viral load assay, Abbott Laboratories, USA).

At the end of fieldwork in each city, a company specializing in biological transport transferred the frozen tubes to the LVM/UFRJ using a single shipment, so confirmatory testing could be performed.

The diagnostic algorithms and interpretations used in this study followed the DCCI's recommendations: (a) HIV infection confirmed by positive Western blot result; (b) active syphilis infection defined by an RPR titer equal to or greater than 1 / 8; (c) viremia period of HBV and HCV infections characterized by a detectable (or quantifiable) viral load.

\section{DATA ANALYSIS}

A database was built using information from SurveyMonkey, the Invitation Manager, and confirmatory lab results.

The magnitude of each participant's network was measured by the following question: "How many sex workers who work here in the city do you know personally, i.e., people who you know and who know you?".

As recommended by Salganik ${ }^{6}$, sample weighting was based on the inverse probability of each participant's selection, proportional to the size of the network, with the exclusion of seeds. Network sizes were limited to the $[3,150]$ interval, that is, values smaller than 3 were replaced by 3 , and values greater than 150 were replaced by 150 , so as to correct outliers ${ }^{27}$. The average size of reported personal networks was 11.54 personally known other sex workers.

For data analysis, the complex design of RDS sampling was considered. Although RDS recruitment is not a classic probabilistic sample, the generated sample can be considered stratified by clusters with different selection probabilities ${ }^{28-30}$. The strata were comprised of the 12 included cities. In each stratum, the weighting was inversely proportional to each 
participant's network size, and together they composed the total strata size. To consider the dependence between observations, each recruiter's invitees were regarded as a cluster ${ }^{31}$.

The effect of homophilia - which can influence the prevalence estimates of HIV and other STIs (i.e., recruiters inviting participants sharing similar personal characteristics) was taken into account ${ }^{20}$. Estimators should be calculated at equilibrium, by composing the conditional prevalence in the negative and positive recruiter groups, respectively ${ }^{28}$.

\section{RESULTS}

Four thousand, three hundred and twenty-eight $(4,328)$ RDS-recruited FSW in 12 Brazilian cities participated in the survey. The minimum sample size was 350 FSW in each city, with 3 coupons distributed to each participant. Primary incentives were offered to all participants, and secondary incentives to all who recruited other women. Thus, the percentage of incentive withdrawal was $100 \%$. Among the women who attended the survey, 70 were not included in the sample because they did not meet the eligibility criteria.

Regarding biological surveillance, venous blood was collected to perform RTs and track HIV, syphilis, and hepatitis B and C infections. Reactive samples from any RT were subsequently subjected to confirmatory testing. Most participants (98.7\%) agreed to collect venous blood in order to carry out RTs followed by confirmatory tests when necessary; $1.2 \%$ agreed only to fingerstick capillary sampling. Only 8 participants refused the collection of any blood sample.

For behavioral surveillance, a socio-behavioral questionnaire was applied in order to obtain the following information: sociodemographic and work characteristics as FSW; knowledge about HIV and other STIs transmission; social support and access to educational and preventive materials; frequency of HIV, syphilis and hepatitis B and C tests; health status and healthcare insurance status; violence; sexual behavior with steady partners and clients; alcohol and drug use.

For data analysis, the sample was weighted according to the size of each participant's network. RDS sampling complex design and the homophilia effect were duly considered.

\section{DISCUSSION}

This research stemmed from the need to continue the baseline started in 2009, performing studies with probabilistic samples to estimate the prevalence rates of HIV, syphilis, hepatitis B and C, and to provide information on risk practices related to HIV among FSW in Brazil. Our second application of the RDS method to FSW, in 2016, allowed for an evaluation of biological and behavioral indicators related to HIV/AIDS and syphilis nine years after the first study, starting a baseline for hepatitis B and $\mathrm{C}^{13}$.

Although RDS methods for obtaining a statistical sample are based on solid statistical premises, allowing for the estimation of statistical parameters as well as statistical inference, with each new application the method has been reassessed. Several data analysis procedures have been proposed, with new suggestions for data weightting and processing. These suggestions are publicly available in the RDS-Analyst software ${ }^{28,29,31-33}$. 
In the whole-sample data analysis, a procedure equivalent to RDS-II ${ }^{29}$ was used; the estimators were found to be robust and consistent with those from $2009^{28,31}$ and from the study with transsexual and transvestite women ${ }^{14}$. The obtained sample, consisting of more than 4,000 FSW across 12 cities, was of great relevance for assessing progress and identifying problems in STI prevention and care.

However, large per-site variations were found, depending on the characteristics of the networks. There were discrepant results in cities that had already been studied in 2009 . These variations are due to the small sample size of 350 participants per city, covering different subsets of the municipal FSW population.

The findings' lack of reproducibility is related to the inclusion of distinct social networks in RDS studies carried out within the same city. The international literature has also reported lack of results reproducibility in RDS studies conducted at the same location over different time periods ${ }^{34}$. One of the limitations of the RDS methodology lies in its very foundation, i.e., the development of networks being driven by participants themselves. In the case of significant homophilia effects, individual characteristics of surveyed participants become similar, especially when the sample is insufficient to represent the diversity of the studied population ${ }^{35}$.

Another factor affecting network development are peer recruitment incentives. The need for obtaining these incentives foster a predominant participation of certain key populations, such as people who use drugs. This occurred in Salvador, where the network was composed of street FSW and drug users, affecting behavioral indicators and leading to the overestimation of HIV prevalence. Thus, the Salvador network does not represent the city's FSW population, but rather a specific network of street workers under very poor living conditions from a restricted area of the city (Figure 3).

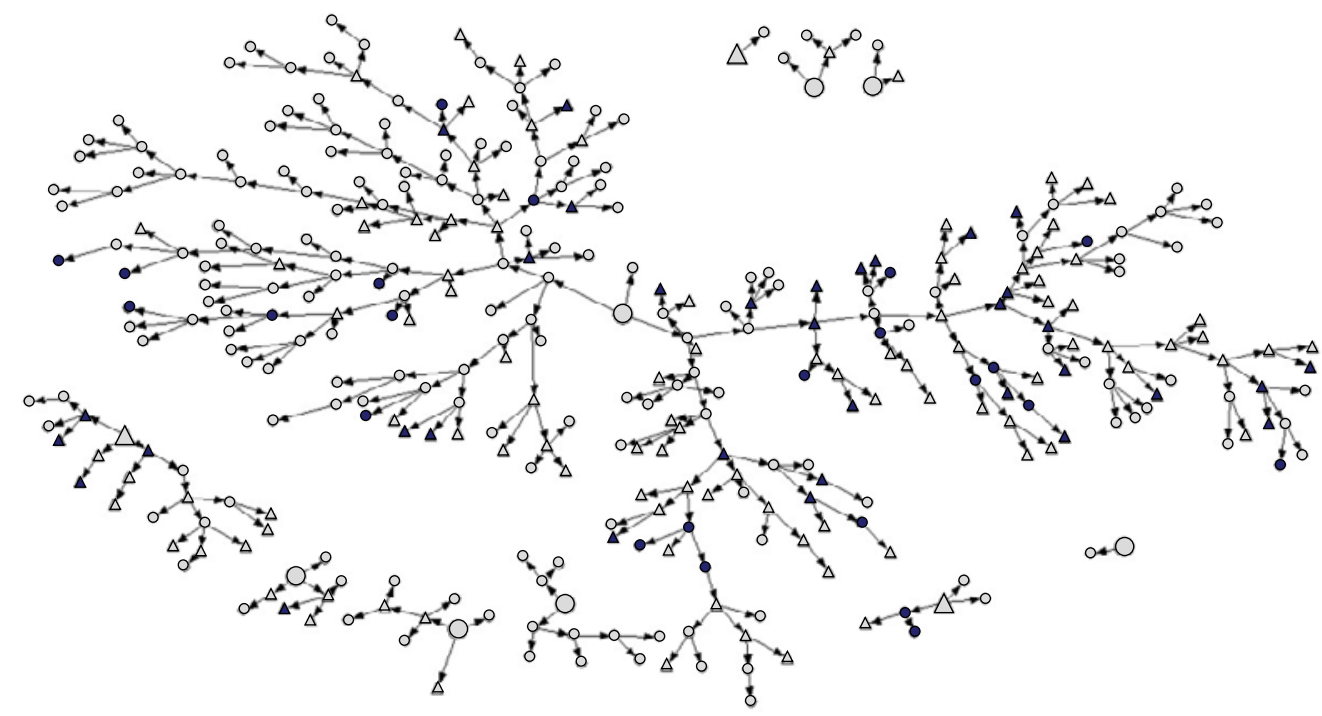

Figure 3. Picture of the Salvador FSW network, 2016.

HIV result (with confirmatory examination): light gray = negative; dark gray = positive. Drug use: circle = no; triangle = yes. Large icons represent seeds. 
In the 2016 RDS research, secondary incentives were necessary to stimulate participation, as time and resources were quite limited. According to Heckathorn ${ }^{7}$, secondary incentives bring forth social influences that bias the sampling process. On the flipside, they attract people under great vulnerability, usually unknown to the health system.

The implementation of secondary incentives needs to be evaluated for its effectiveness in regards to RDS assumptions, since incentives can constitute a parallel currency among individuals at low socioeconomic levels. This can result in duplicates within the sample, participation of non-eligible individuals, and even clashes between individuals in the key population. In the 2016 experience of implementing RDS among FSW in Brazil, the secondary incentive streamlined network development to a short period of fieldwork. On the other hand, in some cities the network was developed faster by more vulnerable, lower socioeconomic-level FSW, motivated by the secondary incentive's monetary gain.

Another important issue regards the minimum sample size per city, which acted as a constraint on network development, disallowing changes in status, characteristics, interests, or, in mathematical language, the transition from a Markov state to another 5

RDS is a methodological advancement, as it provides a probabilistic sample insofar as recruitment procedures are adhered to, using members' own knowledge of key populations to recruit other members. The experience of applying RDS among FSW in 2009 served to facilitate the development of the 2016 study. In addition, the 2009 study established the methodology of analysis for data collected using $\operatorname{RDS}^{5,28}$. We were able to reuse this methodology in the 2016 research.

\section{CONCLUSION}

The 2016 application of the RDS methodology among FSW from 12 Brazilian cities led to a sample of 4,000 participants, which allowed for a comparison with the results of the 2009 study. This comparison facilitates an evaluation of progress and the identification of the challenges that still have to be overcome. The collected information is being used to support public policies for prevention and treatment of STIs in this key population. The analysis of RDS recruitment limitations will be useful for proposing adjustments in the methodology, so more reliable information can be obtained.

\section{REFERENCES}

1. Szwarcwald CL, Souza Júnior PRB. Estimativa da prevalência de HIV na população brasileira de 15 a 49 anos, 2004. Bol Epidemiol AIDS. 2006;3:11-15.

2. Barbosa Júnior A, Szwarcwald CL, Pascom AR, Souza Júnior PRB. Tendências da epidemia de AIDS entre subgrupos sob maior risco no Brasil, 1980-2004. Cad Saúde Pública. 2009,25(4):727-37. http://dx.doi. org/10.1590/S0102-311X2009000400003

3. Magnani R, Sabin K, Saidel T, Heckathorn D. Review of sampling hard-to-reach and hidden populations 
for HIV surveillance. AIDS. 2005;19(Suppl 2):S67-S72. http:/ /dx.doi.org/10.1097/01.aids.0000172879.20628. e1

4. Pascom ARP, Szwarcwald CL, Barbora-Jr A. Sampling studies to estimate the HIV prevalence rate in female commercial sex workers. Braz J Infect Dis. 2010;14(4):385-97. http:/ / dx.doi.org/10.1590/ S1413-86702010000400014

5. Damacena GN, Szwarcwald CL, Barbosa Júnior A. Implementation of respondent-driven sampling among female sex workers in Brazil, 2009. Cad Saúde Pública. 2011;27(Suppl 1):S45-S55. http:/ / dx.doi. org/10.1590/S0102-311X2011001300006

6. Salganik MJ, Heckathorn DD. Sampling and Estimation in Hidden Populations Using Respondent-Driven Sampling. Social Methodology. 2004;34(1):193-240. https: / / doi.org/10.1111/j.0081-1750.2004.00152.x

7. Heckathorn DD. Respondent-Driven Sampling: a new approach to the study of hidden populations. Soc Probl. 1997;44(2):174-99. https://doi. org/10.2307/3096941

8. Johnston LG, Hakim AJ, Dittrich S, Burnett J, Kim E, White RG. A systematic review of published respondent-driven sampling surveys collecting behavioral and biologic data. AIDS Behav. 2016;20(8):1754-76. https:// doi.org/10.1007/ s10461-016-1346-5

9. Malekinejad M, Johnston LG, Kendall C, Kerr LR, Rifkin MR, Rutherford GW. Using respondentdriven sampling methodology for HIV biological and behavioral surveillance in international settings: a systematic review. AIDS Behav. 2008;12(Suppl 4):S10530. https: / / doi.org/10.1007/s10461-008-9421-1

10. Kerr LR, Mota RS, Kendall C, Pinho AA, Mello MB, Guimarães MD, et al. HIV among MSM in a large middle-income country. AIDS. 2013;27(3):427-35. https: / / doi.org/10.1097/ QAD.0b013e32835ad504

11. Toledo L, Codeço CT, Bertoni N, Albuquerque E, Malta M, Bastos FI, Brazilian Multicity Study Group on Drug Misuse. Putting respondent-driven sampling on the map: insights from Rio de Janeiro, Brazil. J Acquir Immune Defic Syndr. 2011;57(Suppl 3):S13643. https: / / doi.org/10.1097/QAI.0b013e31821e9981

12. Kerr L, Kendall C, Guimarães MDC, Salani Mota R, Veras MA, Dourado I, et al. G. HIV prevalence among men who have sex with men in Brazil: results of the 2 nd national survey using respondent-driven sampling. Medicine. 2018;97(1S Suppl 1):S9-15. https: / / doi.org/10.1097/MD.0000000000010573

13. Szwarcwald CL, Almeida WS, Damacena GN, Souza Júnior PRB, Ferreira Júnior ODC, Guimarães MDC. Changes in attitudes, risky practices, and HIV and syphilis prevalence among female sex workers in Brazil from 2009 to 2016. Medicine. 2018;97(1 Suppl 1):S46-S53. https: / / doi.org/10.1097 / MD.0000000000009227

14. Bastos FI, Bastos LS, Coutinho C, Toledo L, Mota JC, Velasco-de-Castro CA, et. al. HIV, HCV, HBV, and syphilis among transgender women from Brazil: assessing different methods to adjust infection rates of a hard-to-reach, sparse population. Medicine. 2018;97(1 Suppl 1):S16-24. https: / / doi.org/10.1097/ MD.0000000000009447

15. Singh TN, Kananbala S, Thongam W, Devi KhS, Singh NB. Increasing trend of HIV seropositivity among commercial sex workers attending the Voluntary and Confidential Counseling and Testing Centre in Manipur, India. Int J STD AIDS. 2005;16(2):166-9. https: / / doi.org/10.1258/0956462053057684

16. Forbi JC, Onyemauwa N, Gyar SD, Oyeleye AO, Entonu P, Agwale SM. High prevalence of hepatitis $B$ virus among female sex workers in Nigeria. Rev Inst Med Trop S Paulo. 2008;50(4):219-21. http:/ / dx.doi.org/10.1590/S0036-46652008000400006

17. Imade G, Sagay A, Egah D, Onwuliri V, Grigg M, Egbodo C, et al. Prevalence of HIV and other sexually transmissible infections in relation to lemon or lime juice douching among female sex workers in Jos, Nigeria. Sex Health. 2008;5(1):55-60.

18. Joint United Nations Programme on HIV/AIDS. Report on the Global AIDS Epidemic. Geneva: UNAIDS; 2008.

19. Brasil. Ministério da Saúde. Secretaria de Vigilância em Saúde. Departamento de DST, Aids e Hepatites Virais. Pesquisa de conhecimento, atitudes e práticas na população brasileira. Brasília, DF; 2016.

20. Ferreira Júnior ODC, Guimarães MDC, Damacena GN, Almeida WS, Souza Júnior PRB, Szwarcwald CL. Prevalence estimates of HIV, syphilis, hepatitis $\mathrm{B}$ and $\mathrm{C}$ among female sex workers (FSW) in Brazil, 
2016. Medicine. 2018;97(1S Suppl 1):S3-S8. https: / / doi.org/10.1097/MD.0000000000009218

21. Johnston LG, Whitehead S, Simic-Lawson M, Kendall C. Formative research to optimize respondentdriven sampling surveys among hard-to-reach populations in HIV behavioral and biological surveillance: lessons learned from four case studies. AIDS Care. 2010;22(6):784-92. https:// doi. org $/ 10.1080 / 09540120903373557$

22. Wylie JL, Jolly AM. Understanding recruitment: outcomes associated with alternate methods for seed selection in respondent driven sampling. BMC Med Res Methodol. 2013;13:93. https://doi. org/10.1186/1471-2288-13-93

23. Johnston LG, Malekinejad M, Kendall C, Iuppa IM, Rutherford GW. Implementation challenges to using respondent-driven sampling methodology for HIV biological and behavioral surveillance: field experiences in international settings. AIDS Behav. 2008;12(4 Suppl):S131-41. https:/ / doi.org/10.1007/ s10461-008-9413-1

24. R Development Core Team. R: a language and environment for statistical computing. Vienna: The $\mathrm{R}$ Foundation for Statistical Computing, Viena, Áustria.

25. SurveyMonkey.com [Internet]. San Mateo, CA [cited 2019 Jun 10]. Available from: https:// pt.surveymonkey.com/

26. Ferreira Jr OC, Franchini M, Bazzo ML, Motta LR, Veras NMC, Wersom ESS, et al. Manual técnico para o diagnóstico da infecção pelo HIV. Brasília, DF: Ministério da Saúde, Secretaria de Vigilância em Saúde, Departamento de Vigilância, Prevenção e Controle das Doenças Sexualmente Transmissíveis, Aids e Hepatites Virais; 2015.

27. Gonçalves B, Perra N, Vespignani A. Modeling users' activity on Twitter networks: validation of Dunbar's number. PLoS ONE. 2011; 6(8):e22656. https:/ / doi. org/10.1371/journal.pone.0022656

28. Szwarcwald CL, de Souza Júnior PR, Damacena GN, Junior AB, Kendall C. Analysis of data collected by RDS among sex workers in 10 Brazilian cities, 2009: estimation of the prevalence of HIV, variance, and design effect. J Acquir Immune Defic Syndr. 2011;57(Suppl 3):S129-35. https:/ / doi.org/10.1097/ QAI.0b013e31821e9a36
29. Handcock MS, Gile KJ, Mar CM. Estimating hidden population size using Respondent-Driven Sampling data. Electron J Stat 2014;8(1):1491-1521. https: / / doi.org/10.1214/14-EJS923

30. Gile KJ, Handcock MS. Respondent-Driven Sampling: an assessment of current methodology. Sociol methodol. 2010;40(1):285-327. https:// doi. org/10.1111/j.1467-9531.2010.01223.x

31. Heckathorn DD, Semaan S, Broadhead RS, Hughes JJ. Extensions of Respondent-Driven Sampling: a new approach to the study of injection drug users aged 18-25. AIDS Behav 2002;6(1):55-67. https:// doi.org/10.1023/A:1014528612685

32. Abdul-Quader AS, Heckathorn DD, Sabin K, Saidel T. Implementation and analysis of respondent driven sampling: lessons learned from the field. J Urban Health 2006;83(6 Suppl):i1-5. https: / / doi. org/10.1007/s11524-006-9108-8

33. Salganik M. Variance estimation, design effects, and sample size calculations for respondent-driven sampling. J Urban Health 2006;83(6 Suppl):i98-112. https: / / doi.org/10.1007/s11524-006-9106-x

34. Khatib A, Haji S, Khamis M, Said C, Khalid F, Dahoma M, et al. Reproducibility of RespondentDriven Sampling (RDS) in repeat surveys of men who have sex with men, Unguja, Zanzibar. AIDS Behav 2017;21(7):2180-7. https: / / doi.org/10.1007/ s10461-016-1632-2

35. Kuhns LM, Kwon S, Ryan DT, Garofalo R, Phillips G 2nd, Mustanski BS. Evaluation of respondent-driven sampling in a study of urban young men who have sex with men. J Urban Health 2015; 92(1):151-67. https: / / doi.org/10.1007/s11524-014-9897-0

\section{Received on: 01/07/2019 \\ Final version presented on: 06/18/2019 \\ Accepted on: 07/03/2019}

Acknowledgments: To each female sex worker who participated in the study and to all collaborators, including NGOs, focal points, and members of the local study teams. To the Ministry of Health's Department of Chronic Condition Diseases and Sexually Transmitted Infections.

Authors' contribution: Damacena GN conceived and elaborated the article, besides coordinating field work. Szwarcwald CL collaborated in the writing of the text, 
was responsible for the overall coordination of the research and, along with Damacena GN and Souza Júnior PRB, proposed the analysis methodology. Damacena GN, Souza Júnior PRB and Almeida WS prepared the tables and figures. Ferreira Júnior OC prepared the methodology of laboratory tests and coordinated the laboratory research. Pascom ARP built the questionnaire and, together with Pimenta MC, collaborated with article discussion. All authors reviewed and approved the final version of the article. 